ASTHMA

\title{
Functional $\mathrm{K}_{\mathrm{Ca}} 3.1 \mathrm{~K}^{+}$channels are required for human lung mast cell migration
} G Cruse, S M Duffy, C E Brightling, P Bradding

See end of article for authors' affiliations

Correspondence to: Mr G Cruse, Department of Respiratory Medicine, Glenfield Hospital, Groby Road, Leicester LE3 9QP, UK; glenncruse@hotmail. com

Received 3 February 2006 Accepted 7 June 2006 Published Online First 29 June 2006
Background: Mast cell recruitment and activation are critical for the initiation and progression of inflammation and fibrosis. Mast cells infiltrate specific structures in many diseased tissues such as the airway smooth muscle (ASM) in asthma. This microlocalisation of mast cells is likely to be key to disease pathogenesis. Human lung mast cells (HLMC) express the $\mathrm{Ca}^{2+}$ activated $\mathrm{K}^{+}$channel $\mathrm{K}_{\mathrm{Ca}} 3.1$ which modulates mediator release, and is proposed to facilitate the retraction of the cell body during migration of several cell types. A study was undertaken to test the hypothesis that blockade of $\mathrm{K}_{\mathrm{Ca}} 3.1$ would attenuate HLMC proliferation and migration.

Methods: HLMC were isolated and purified from lung material resected for bronchial carcinoma. HLMC proliferation was assessed by cell counts at various time points following drug exposure. HLMC chemotaxis was assayed using standard Transwell chambers ( $8 \mu \mathrm{m}$ pore size). lon currents were measured using the single cell patch clamp technique.

Results: $\mathrm{K}_{\mathrm{Ca}} 3.1$ blockade with triarylmethane-34 (TRAM-34) did not inhibit HLMC proliferation and clotrimazole had cytotoxic effects. In contrast, HLMC migration towards the chemokine CXCL10, the chemoattractant stem cell factor, and the supernatants from tumour necrosis factor $\alpha$ stimulated asthmatic ASM was markedly inhibited with both the non-selective $\mathrm{K}_{\mathrm{Ca} 3.1}$ blocker charybdotoxin and the highly specific $\mathrm{K}_{\mathrm{Ca}} 3.1$ blocker TRAM-34 in a dose dependent manner. Although $\mathrm{K}_{\mathrm{Ca}} 3.1$ blockade inhibits $\mathrm{HLMC}$ migration, $\mathrm{K}_{\mathrm{Ca}} 3.1$ is not opened by the chemotactic stimulus, suggesting that it must be involved downstream of the initial receptor-ligand interactions.

Conclusions: Since modulation of $\mathrm{K}_{\mathrm{Ca}} 3.1$ can inhibit HLMC chemotaxis to diverse chemoattractants, the use of $\mathrm{K}_{\mathrm{Ca}} 3.1$ blockers such as TRAM-34 could provide new therapeutic strategies for mast cell mediated diseases such as asthma.
M ast cells are major effector cells in many different inflammatory and fibrotic diseases including asthma, pulmonary fibrosis, and rheumatoid arthritis. ${ }^{1}$ In these diseases there is evidence of increased mast cell numbers within specific tissue structures, ${ }^{23}$ where they contribute to the immunopathology through the release of a plethora of pleiotropic autacoids, proteases, and cytokines. ${ }^{1}$ For example, in asthma, mast cells infiltrate the airway smooth muscle (ASM) bundles in the airways of asthmatic subjects, but not those of either patients with eosinophilic bronchitis or normal subjects. ${ }^{2}$ This event is likely to be key in the development of the disordered ASM physiology of asthma. Similarly, in rheumatoid disease there is accumulation of mast cells in the pannus at the edge of articular cartilage erosion. ${ }^{3}$ It follows from this that targeting mast cell migration to these sites may offer a novel means of treating diseases in which mast cells play a role.

We have recently shown that ASM cell derived CXCL10 (also known as interferon- $\gamma$ inducible protein of $10 \mathrm{kDa}$ (IP10)) induces human lung mast cell (HLMC) chemotaxis. ${ }^{4}$ CXCL10 induces HLMC migration by binding to the chemokine receptor CXCR3 which is preferentially expressed on mast cells within the ASM of asthmatic subjects. ${ }^{5}$ Inhibition of the CXCL10/CXCR3 axis could therefore provide a new and effective treatment for asthma. However, in addition to CXCL10, the ASM produces several other mast cell chemoattractants including stem cell factor $(\mathrm{SCF}){ }^{6}$ transforming growth factor $\beta(\mathrm{TGF} \beta),{ }^{7}$ and the chemokines CXCL8, CXCL12 and CCLl1. ${ }^{5}$ A more general approach to preventing mast cell migration may therefore demonstrate better efficacy in the treatment of asthma and other mast cell mediated diseases than targeting of specific chemokines.
Ion channels are emerging as interesting therapeutic targets in both inflammatory and structural non-excitable cells. ${ }^{8} 9$ HLMC, human bone marrow derived and human peripheral blood derived mast cells express the intermediate conductance $\mathrm{Ca}^{2+}$ activated $\mathrm{K}^{+}$channel, $\mathrm{K}_{\mathrm{Ca}} 3.1$ (also known as $\left.\mathrm{IK}_{\mathrm{Ca}} 1\right) .{ }^{10-12}$ This channel maintains a negative membrane potential during cell activation, thus increasing the driving potential for $\mathrm{Ca}^{2+}$ influx through store operated calcium channels. ${ }^{13}$ Blockade of $\mathrm{K}_{\mathrm{Ca}} 3.1$ therefore attenuates HLMC degranulation while opening it enhances it. ${ }^{10}{ }^{11}$ In addition to their role in cell activation, ion channels carrying $\mathrm{K}^{+}$and $\mathrm{Cl}^{-}$ have been implicated in many diverse cellular processes including proliferation, chemotaxis, and apoptosis. $\mathrm{K}_{\mathrm{Ca}}$ channels are required for lysophosphatidic acid induced microglial cell migration ${ }^{14}$ and evidence also exists for the involvement of $\mathrm{K}_{\mathrm{Ca}} 3.1$ in both $\mathrm{T}$ and $\mathrm{B}$ cell proliferation. ${ }^{15}$

In this study we have examined the hypothesis that $\mathrm{K}_{\mathrm{Ca}} 3.1$ is important for HLMC migration and proliferation. To test this we examined the effects of $\mathrm{K}_{\mathrm{Ca}} 3.1$ blockade with the relatively non-selective $\mathrm{K}_{\mathrm{Ca}} 3.1$ blocker charybdotoxin and the highly specific $\mathrm{K}_{\mathrm{Ca}} 3.1$ blocker triarylmethane-34 (TRAM-34) on HLMC migration induced by CXCL10, SCF, and ASM. We also studied the effect of the $\mathrm{K}_{\mathrm{Ca}} 3.1$ blockers TRAM-34 and clotrimazole on HLMC proliferation.

\section{METHODS \\ Reagents}

The following were purchased: recombinant human (rh)SCF, rhIL-6, rhIL-10, rhCXCL10 (R\&D, Abingdon, UK);

Abbreviations: $A S M$, airway smooth muscle; HLMC, human lung mast cell; IL, interleukin; SCF, stem cell factor; TGF- $\beta$, transforming growth factor $\beta$; TNF- $\alpha$, tumour necrosis factor $\alpha$; TRAM-34, triarylmethane-34 
1-ethyl-2-benzimidazolinone (1-EBIO), charybdotoxin, iberiotoxin (Sigma, Poole, Dorset, UK); mouse IgG $_{1}$ mAb YB5.B8 (anti-CD117) (Cambridge Bioscience, Cambridge, UK); sheep

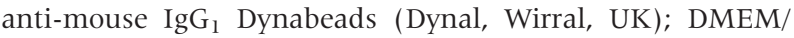
Glutamax/Hepes, antibiotic/antimycotic solution, MEM nonessential amino acids and foetal calf serum (FCS) (Life Technologies, Paisley, UK). TRAM-34 was a generous gift from Dr Heike Wulff (University of California Irvine, California, USA).

\section{HLMC purification}

HLMC were dispersed enzymatically from macroscopically normal lung obtained within 1 hour of resection for lung cancer and purified using immunoaffinity magnetic selection (Dynabeads) as described previously. ${ }^{10}$ The final mast cell purity, assessed using metachromatic staining, was $>99 \%$ with cell viability $>98 \%$ (monitored by exclusion of trypan blue). HLMC were cultured in DMEM/Glutamax/Hepes containing $1 \%$ antibiotic/antimycotic solution, $1 \%$ nonessential amino acids, 10\% FCS, $100 \mathrm{ng} / \mathrm{ml} \mathrm{SCF}, 50 \mathrm{ng} / \mathrm{ml}$ IL-6, and $10 \mathrm{ng} / \mathrm{ml} \mathrm{IL-10.}$

\section{HLMC proliferation assay}

Following purification, HLMC were resuspended in DMEM/ Glutamax/Hepes containing SCF $(100 \mathrm{ng} / \mathrm{ml})$, interleukin (IL) $-6(50 \mathrm{ng} / \mathrm{ml})$, and IL-10 $(10 \mathrm{ng} / \mathrm{ml})$ at a concentration of $0.25 \times 10^{6}$ cells $/ \mathrm{ml}$ as described previously. ${ }^{16}$ Clotrimazole and TRAM-34 were added in the concentration range 10$1000 \mathrm{nM}$. Control wells containing either $0.1 \%$ dimethyl sulphoxide (DMSO) or culture medium alone were also established. Metachromatic cells were counted after 1 and 4 weeks in culture using Kimura stain.

\section{HLMC chemotaxis}

HLMC chemotaxis assays were performed using the Transwell system (BD Biosciences, Oxford, UK) with 24 well plates as described previously. ${ }^{4}$ CXCL10 or SCF was placed in the lower wells (omitted in negative control) at a concentration of $100 \mathrm{ng} / \mathrm{ml} .50 \mu \mathrm{l}$ of $2 \times$ the final concentration of TRAM-34 (final concentration 20 or $200 \mathrm{nM}$ ), charybdotoxin or iberiotoxin (final concentration of $100 \mathrm{nM}$ ) was added to the upper chambers immediately before the addition of $1 \times 10^{5}$ HLMC per well $(50 \mu \mathrm{l})$. The vehicle for TRAM-34 was DMSO and the final concentration of DMSO was $0.1 \%$ in all wells including a control. After incubating the cells for 3 hours at $37^{\circ} \mathrm{C}$, the number of HLMC in the bottom well was counted using Kimura stain in a haemocytometer. HLMC migration was calculated as the fold increase of migrated cells in the test wells compared with the negative control (no chemoattractant in the lower well) as described previously. ${ }^{45}$

ASM cells (passage 3-7) from subjects with asthma $(\mathrm{n}=4)$ were plated into six-well plates $\left(9.6 \times 10^{4}\right.$ cells $/ 2 \mathrm{ml}$ DMEM, $10 \%$ fetal calf serum), grown for 1 week, then growth was arrested for 48 hours with serum deprived medium and stimulated with tumour necrosis factor $(\mathrm{TNF})-\alpha(10 \mathrm{ng} / \mathrm{ml})$ for 24 hours. ${ }^{5}$ The supernatants were removed and stored at $-80^{\circ} \mathrm{C}$ before use in the chemotaxis experiments.

\section{Patch clamp electrophysiology}

The whole cell variant of the patch clamp technique was used. ${ }^{10}$ Patch pipettes were made from borosilicate fibre containing glass (Clark Electromedical Instruments, Reading, UK) and their tips were heat polished resulting in resistances of typically 4-6 $\mathrm{M} \Omega$. The standard pipette solution contained (in $\mathrm{mM}$ ): $\mathrm{KCl}, 140 ; \mathrm{MgCl}_{2}, 2$; HEPES, 10; $\mathrm{Na}^{+} \mathrm{ATP}, 2$; GTP, $0.1 ; \mathrm{pH}$ 7.3. The standard external solution contained (in $\mathrm{mM})$ : $\mathrm{NaCl}, 140 ; \mathrm{KCl}, 5, \mathrm{CaCl}_{2}, 2 ; \mathrm{MgCl}_{2}, \mathrm{l} ;$ HEPES, 10; $\mathrm{pH}$
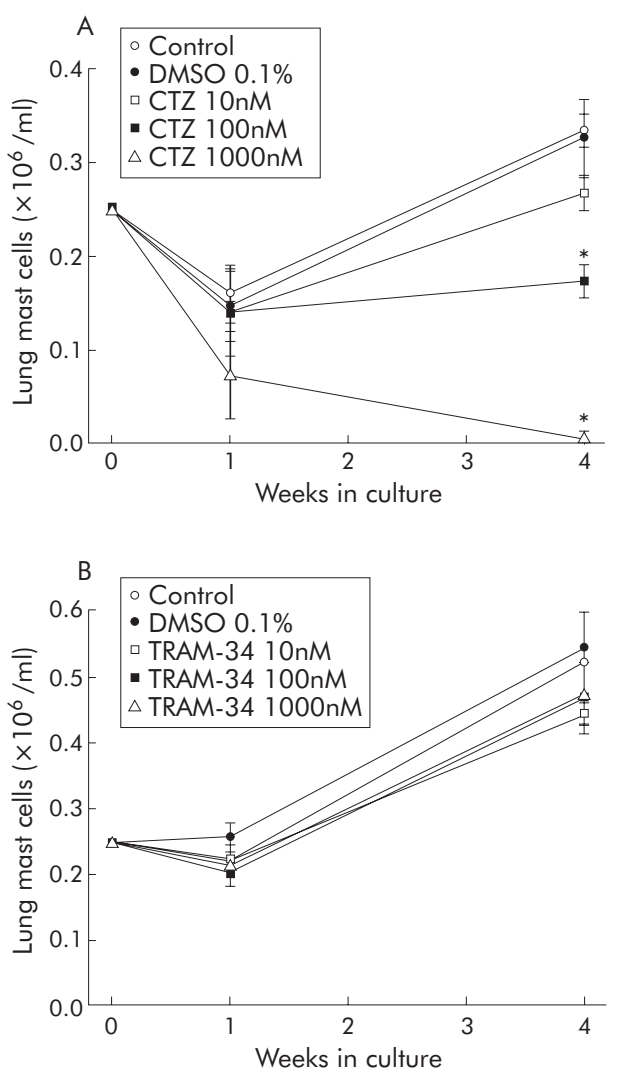

Figure $1 \mathrm{HLMC}$ proliferation in long term culture. (A) HLMC proliferation was attenuated dose dependently by the addition of clotrimazole (CTZ). Higher concentrations ( $\mu M$ ) of clotrimazole killed the cells. (B) Conversely, triarylmethane-34 (TRAM-34) had no significant effect on HLMC proliferation. Drug concentrations are given in $\mathrm{nmol} / \mathrm{I}$ and data are mean (SE) values from three separate donors. Donors in (A) are different from those in (B). ${ }^{*} \mathrm{p}<0.05$

7.3. For recording, mast cells were placed in $35 \mathrm{~mm}$ dishes containing standard external solution.

Whole cell currents were recorded using an Axoclamp 200A amplifier (Axon Instruments, Foster City, CA, USA), and currents evoked by applying voltage commands to a range of potentials ( 120 to $+130 \mathrm{mV}$ ) in $10 \mathrm{mV}$ steps from a holding potential of $-20 \mathrm{mV}$. The currents were digitised (sampled at a frequency of $10 \mathrm{kHz}$ ), stored on computer, and subsequently analysed using pClamp software (Axon Instruments). Capacitance transients were minimised using the capacitance neutralisation circuits on the amplifier. Correction for series resistance was not routinely applied. In some experiments continuous membrane currents were recorded at a constant holding potential of $+40 \mathrm{mV}$, data being digitised at $200 \mathrm{~Hz}$ and recorded using Axoscope (Axon Instruments). Experiments were performed at $27^{\circ} \mathrm{C}$, the temperature being controlled by a Peltier device. Experiments were performed with a perfusion system (Automate Scientific Inc, San Francisco, CA, USA) to allow solution changes, although drugs were added directly to the recording chamber.

\section{Data presentation and statistical analysis}

Data are presented as mean (SE) values from separate donors performed in duplicate. Confidence intervals were calculated at 95\% using Graphpad Prism 4 software. The inhibition of chemotaxis is presented as the percentage migration compared with the positive control after the subtraction of the negative control from all conditions. Differences between 


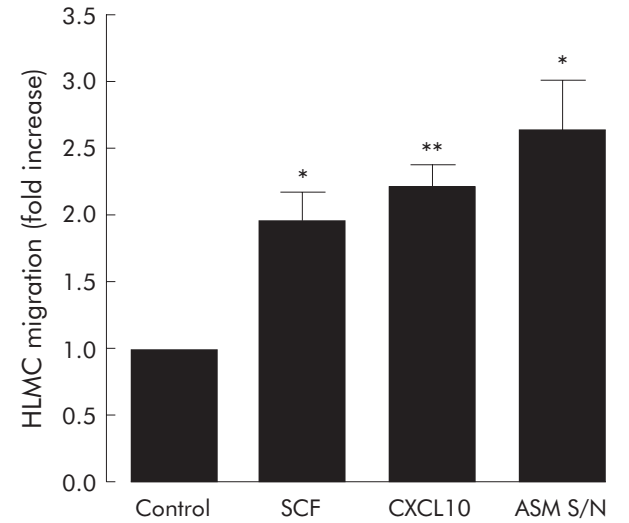

Figure 2 Effect of stem cell factor (SCF, n=4), CXCL10 ( $n=6)$, and supernatants from tumour necrosis factor (TNF) $\alpha$ stimulated asthmatic airway smooth muscle (ASM, $n=4)$ on HLMC migration. Data are presented as mean (SE) values from at least four individual donors. ${ }^{*} p<0.05 ;{ }^{* *} p<0.01$.

data sets were analysed using a paired two tailed Student's $t$ test (Microsoft Excel v2003). p values of $<0.05$ were considered statistically significant.

All human subjects gave written informed consent and the study was approved by the Leicestershire Research Ethics Committee.

\section{RESULTS}

\section{HLMC proliferation}

HLMC proliferate in long term culture. ${ }^{16}$ Clotrimazole, a blocker of $\mathrm{K}_{\mathrm{Ca}} 3.1$ ( $K_{\mathrm{d}} 70 \mathrm{nM}$ ) and inhibitor of cytochrome P450, produced a dose dependent reduction in HLMC number after 4 weeks in culture, with complete cell death evident at $1000 \mathrm{nM}$ (fig 1A). In contrast, TRAM-34, a highly specific blocker of $\mathrm{K}_{\mathrm{Ca}} 3.1\left(K_{\mathrm{d}} 20 \mathrm{nM}\right)$ without any effect on cytochrome P450, had no effect on HLMC at 1 or 4 weeks (fig $1 \mathrm{~B}$ ). This suggests that $\mathrm{K}_{\mathrm{Ca}} 3.1$ is not involved in HLMC proliferation and that the effects of clotrimazole were "toxic" and independent of its effect on $\mathrm{K}_{\mathrm{Ca}} 3.1$. This is in contrast to the role of $\mathrm{K}_{\mathrm{Ca}} 3.1$ in human $\mathrm{T}$ lymphocyte proliferation. ${ }^{15}$

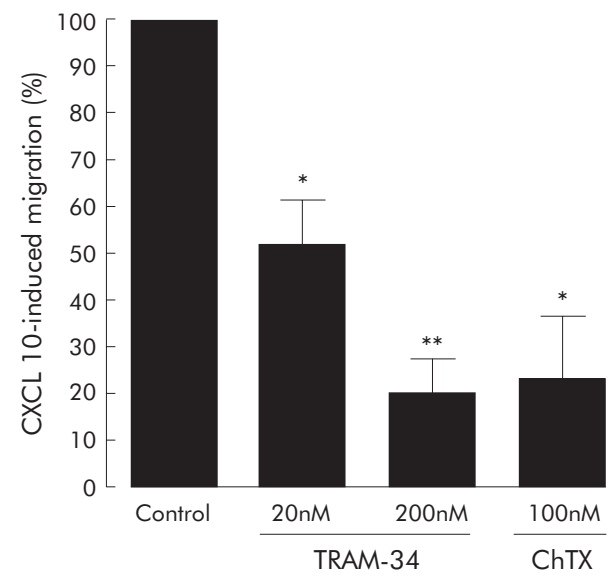

Figure 3 Aftenuation of $\mathrm{CXCL} 10$ induced $\mathrm{HLMC}$ migration with $\mathrm{K}_{\mathrm{Ca}^{3}} 3.1$ blockade. Triarylmethane-34 (TRAM-34) attenuated CXCL-10 induced HLMC migration in a dose dependent manner. The pharmacologically distinct $\mathrm{K}_{\mathrm{Ca}} 3.1$ blocker charybdotoxin (ChTX) attenuated CXCL10 induced HLMC migration with similar efficacy to TRAM-34. Data are mean (SE) values from six separate donors. ${ }^{*} p<0.005 ;{ }^{* *} p<0.001$.

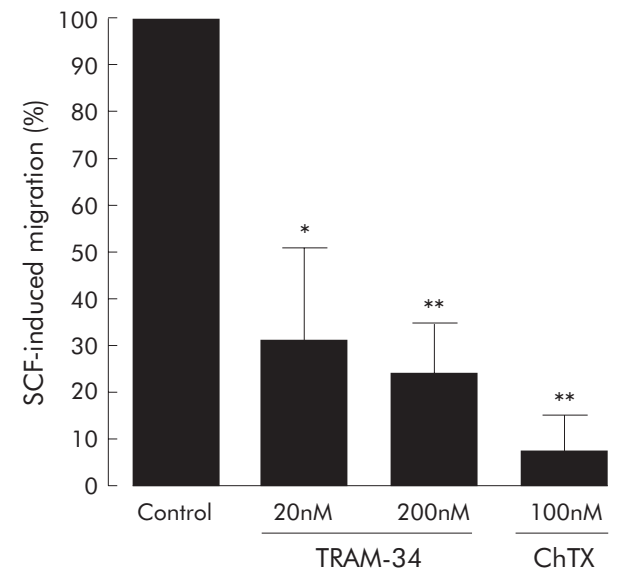

Figure 4 Attenuation of stem cell factor (SCF) induced HLMC migration with $\mathrm{K}_{\mathrm{Ca}} 3.1$ blockade. Blockade of $\mathrm{K}_{\mathrm{Ca}} 3.1$ attenuated SCF induced HLMC migration with similar efficacy to CXCL10 induced HLMC migration. Data are mean (SE) from four separate donors. TRAM-34, triarylmethane-34; ChTX, charybdotoxin. ${ }^{*} \mathrm{p}<0.05$; ${ }^{* *} \mathrm{p}<0.01$.

\section{HLMC chemotaxis}

Because of its apparent toxic effect on HLMC, clotrimazole was not used in the chemotaxis assays. For blockade of $\mathrm{K}_{\mathrm{Ca}} 3.1$ during chemotaxis we used TRAM-34 and another $\mathrm{K}_{\mathrm{Ca}} 3.1$ blocker, charybdotoxin $\left(K_{\mathrm{d}} 5 \mathrm{nM}\right)$.

The migration of HLMC in response to $100 \mathrm{ng} / \mathrm{ml} \mathrm{CXCL10}$ was $2.2(0.2)$ fold greater than that of the control (no CXCL10, $\mathrm{n}=6$; 95\% CI 1.7 to 2.7, $\mathrm{p}=0.001$, fig 2), in keeping with previous experiments. ${ }^{4}$ CXCL10 induced migration was inhibited dose dependently by TRAM-34. Thus, with $200 \mathrm{nM}$ TRAM-34 migration was reduced by $80(7) \%(n=6 ; 95 \%$ CI 62 to $99, \mathrm{p}=0.0001$, fig 3). Consistent with this, CXCL10 induced HLMC migration was inhibited by 78 (14)\% with the addition of $100 \mathrm{nM}$ charybdotoxin $(\mathrm{n}=6$; $95 \%$ CI 42 to 113 , $\mathrm{p}=0.002$, fig 3).

To determine whether the inhibition of HLMC migration by $\mathrm{K}_{\mathrm{Ca}} 3.1$ blockade was restricted to an interaction with $\mathrm{G}$ protein coupled chemoattractants or a general phenomenon,

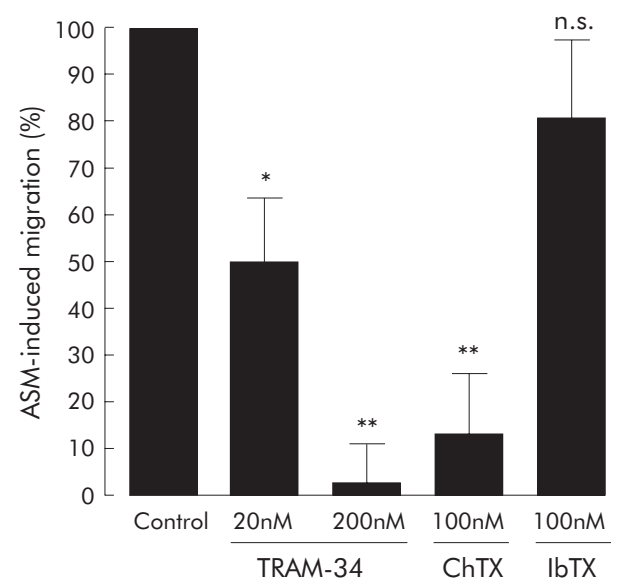

Figure 5 Attenuation of HLMC migration towards tumour necrosis factor (TNF)- $\alpha$ stimulated asthmatic ASM supernatants with $\mathrm{K}_{\mathrm{Ca}^{3}} 3.1$ blockade. Triarylmethane-34 (TRAM-34) attenuated HLMC migration to ASM supernatants in a dose dependent manner. Charybdotoxin (ChTX) inhibited migration with similar efficacy to TRAM-34. Iberiotoxin (IbTX), which is structurally related to charybdotoxin but does not block $\mathrm{K}_{\mathrm{Ca}} 3.1$, had no significant effect on HLMC migration. Data are presented as mean (SE) values from four separate donors. ${ }^{*} p<0.05$; ${ }^{* *} p<0.01$; NS, not significant. 

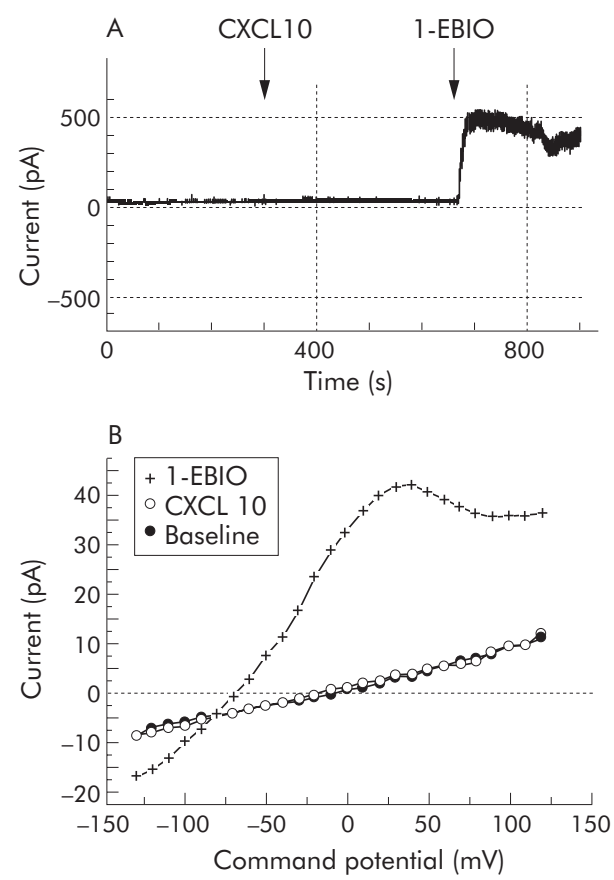

Figure 6 Whole cell electrophysiological recording of electrical currents in HLMC at rest and following the addition of CXCL10 and then 1-ethyl-2-benzimidazolinone (1-EBIO). (A) Continuous recording of current at $+40 \mathrm{mV}$ in an HLMC showing a stable baseline with minimal basal current. No response was seen to the addition of CXCL10 where indicated, but a rapid increase in outward current occurred within 90 seconds of adding 1-EBIO to the recording chamber. (B) Currentvoltage curves from another cell at rest 3 minutes after the addition of CXCL10 and then 3 minutes after the addition of 1 -EBIO showing development of a typical $\mathrm{K}_{\mathrm{Ca}} 3.1$ whole cell current following the latter.

we next tested the effects of TRAM-34 and charybdotoxin on SCF induced migration. SCF $(100 \mathrm{ng} / \mathrm{ml})$ induced HLMC migration to a similar extent as CXCL10 in the majority of donors with mean migration of $2.0(0.2)$ fold compared with control $(\mathrm{n}=4,95 \%$ CI 1.3 to 2.6, $\mathrm{p}=0.020$, fig 2). Charybdotoxin (100 nM) and TRAM-34 (200 nM) inhibited SCF induced migration by $92(8) \%(\mathrm{n}=4,95 \%$ CI 69 to 116 , $\mathrm{p}=0.001)$, and $76(11) \%(\mathrm{n}=4,95 \%$ CI 42 to $110, \mathrm{p}=0.006)$, respectively (fig 4 ).

As a further control we also examined the effects of the specific large conductance $\mathrm{Ca}^{2+}$ activated $\mathrm{K}^{+}$channel $\left(\mathrm{K}_{\mathrm{Ca}} \mathrm{l}\right.$.1, also known as $\mathrm{BK}_{\mathrm{Ca}}$ ) blocker iberiotoxin ( $100 \mathrm{nM}$ ). Since HLMC do not express $\mathrm{K}_{\mathrm{Ca}} 1.1$ currents or mRNA, ${ }^{10} 22$ iberiotoxin should be ineffective. Indeed, iberiotoxin did not attenuate the migration of HLMC to either CXCL10 or SCF $(2.0(0.6)$ fold in the control compared with $1.8(0.5)$ fold with $100 \mathrm{nM}$ iberiotoxin). Background control migration was not inhibited by charybdotoxin or TRAM-34.

Since HLMC migration to SCF and CXCL10 was inhibited with similar efficacy, we next examined the effects of $\mathrm{K}_{\mathrm{Ca}} 3.1$ blockade on HLMC migration towards the complex milieu of chemoattractants present in cell supernatants from stimulated asthmatic ASM. The ASM supernatants induced HLMC migration to a greater extent than either CXCL10 or SCF alone, with mean migration of $2.6(0.4)$ fold compared with control $(\mathrm{n}=4,95 \%$ CI 1.5 to $3.8, \mathrm{p}=0.022$, fig 2$)$. Both charybdotoxin (100 nM) and TRAM-34 (200 nM) inhibited HLMC migration to ASM supernatants with similar efficacy as with CXCL10 or SCF alone, with 87 (12)\% inhibition of migration with charybdotoxin $(\mathrm{n}=4,95 \%$ CI 47 to 126 , $\mathrm{p}=0.006)$ and $97(8) \%$ inhibition with TRAM-34 $(\mathrm{n}=4,95 \%$ CI 72 to $123, p=0.001$, fig 5). In contrast, iberiotoxin did not attenuate the migration of HLMC towards ASM supernatants
(2.6 (0.4) fold in the control compared with $2.4(0.5)$ fold with $100 \mathrm{nM}$ iberiotoxin) ( $\mathrm{n}=4,95 \%$ CI 0.9 to $4.0, \mathrm{p}=0.538$, fig 5).

\section{Effects of $\mathrm{CXCL} 10$ on HLMC $\mathrm{K}_{\mathrm{Ca}^{3}} 3.1$ activation}

We have recently shown that the $G_{\alpha s}$ coupled $\beta_{2}$ adrenoceptor influences $\mathrm{K}_{\mathrm{Ca}} 3.1$ gating. ${ }^{17}$ To assess whether the $\mathrm{G}_{\alpha \mathrm{i}}$ coupled CXCL10 receptor CXCR3 influences $\mathrm{K}_{\mathrm{Ca}} 3.1$ function we attempted to record $\mathrm{K}_{\mathrm{Ca}} 3.1$ currents following the addition of $100 \mathrm{ng} / \mathrm{ml}$ CXCL10 to HLMC $(n=23$ cells from four separate donors). In spite of being able to record $\mathrm{K}_{\mathrm{Ca}} 3.1$ currents in these cells following the addition of the $\mathrm{K}_{\mathrm{Ca}} 3.1$ specific channel opener 1-ethyl-2-benzimidazolinone (1EBIO), we did not see any evidence of either the transient or sustained opening of $\mathrm{K}_{\mathrm{Ca}} 3.1$ in response to CXCL10 (fig 6).

\section{DISCUSSION}

In this study we have shown for the first time that blockade of the $\mathrm{K}^{+}$channel $\mathrm{K}_{\mathrm{Ca}} 3.1$ markedly attenuates the chemotactic response of ex vivo HLMC to the chemokine CXCL10, the mast cell growth factor SCF, and conditioned media from asthmatic ASM. In contrast to its effects on acute mitogen induced lymphocyte proliferation, $\mathrm{K}_{\mathrm{Ca}} 3.1$ does not appear to be important for HLMC proliferation in long term culture.

The redistribution of mast cells within human tissues is likely to be key in the initiation and propagation of a variety of diseases. ${ }^{2}{ }^{3}$ Inhibiting their migration within tissues may therefore offer a truly novel approach for the treatment of mast cell driven pathobiology. As an example, we have recently shown that the CXCL10/CXCR3 axis may be a critical determinant of mast cell distribution within the human lung. ${ }^{5}$ Thus, inhibition of CXCL10/CXCR3 induced chemotaxis is an attractive target for asthma therapy. However, while targeting CXCL10/CXCR3 may prove fruitful, the ASM produces several other chemoattractants including SCF, TGF $\beta$ and other chemokines. ${ }^{5-7}$ These may play their own part in mast cell recruitment by ASM under certain conditions and, in addition, are probably important for the microlocalisation of mast cells within other tissue compartments in unrelated diseases such as tubulointerstitial renal disease and rheumatoid arthritis. ${ }^{23} 18$ The ability of $\mathrm{K}_{\mathrm{Ca}} 3.1$ blockade profoundly to inhibit mast cell migration in response to two diverse chemoattractants-CXCL10 which activates the G protein coupled receptor CXCR3 and SCF which activates the tyrosine kinase receptor CD117-therefore suggests that $\mathrm{K}_{\mathrm{Ca}} 3.1$ has great potential as a therapeutic target for mast cell mediated disease in humans. Moreover, blockade of $\mathrm{K}_{\mathrm{Ca}} 3.1$ almost completely attenuates HLMC migration towards the complex milieu of chemoattractants present in TNF $\alpha$ stimulated asthmatic ASM cell supernatants, strengthening the hypothesis that functional $\mathrm{K}_{\mathrm{Ca}} 3.1$ channels are an absolute requirement for HLMC migration.

To inhibit HLMC migration we used charybdotoxin and TRAM-34, two distinct molecules which block the $\mathrm{K}_{\mathrm{Ca}} 3.1$ pore at different sites. ${ }^{19}{ }^{20}$ Charybdotoxin is a 37 amino acid peptide derived from the venom of the scorpion Leiurus quinquestriatus and blocks $\mathrm{K}_{\mathrm{Ca}} 3.1$ with a $K_{\mathrm{d}}$ for channel block of 5-10 nM. ${ }^{19}{ }^{21}$ It also blocks the voltage gated $\mathrm{K}^{+}$channel $\mathrm{K}_{\mathrm{V}} \mathrm{l} .3$ and the large conductance $\mathrm{K}_{\mathrm{Ca}}, \mathrm{K}_{\mathrm{Ca}}$ l.l. However, HLMC do not express $\mathrm{K}_{\mathrm{v}} 1.3$ or $\mathrm{K}_{\mathrm{Ca}} 1.1$ mRNA or their electrical currents. ${ }^{10} 22$ TRAM-34 is a highly specific small molecule blocker of $\mathrm{K}_{\mathrm{Ca}} 3.1\left(K_{\mathrm{d}} 20 \mathrm{nM}\right)^{23}$ which was derived from the $\mathrm{K}_{\mathrm{Ca}} 3.1$ blocker and antifungal agent clotrimazole. However, unlike clotrimazole, TRAM-34 does not interfere with cytochrome $\mathrm{P}^{2} 50 .{ }^{23}$ Charybdotoxin blocks $\mathrm{K}_{\mathrm{Ca}} 3.1$ by binding to the external pore with high affinity, ${ }^{19}$ while the highly lipophilic TRAM-34 binds to residues within the internal vestibule of the channel. ${ }^{20}$ We used TRAM-34 and charybdotoxin at concentrations up to 10 times the $K_{\mathrm{d}}$ 
because it has been estimated previously that, for complete channel block to be achieved, drugs need to be present at 510 times the $K_{\mathrm{d}} \cdot{ }^{15}$ The ability of these two potent but pharmacologically distinct $\mathrm{K}_{\mathrm{Ca}} 3.1$ blockers to inhibit HLMC migration to a similar extent at 10 times the $K_{\mathrm{d}}$ therefore indicates that the mechanism behind this is indeed $\mathrm{K}_{\mathrm{Ca}} 3.1$ blockade. In addition, the $\mathrm{K}_{\mathrm{Ca}} 1.1$ blocker iberiotoxin was without effect, further suggesting that the effects observed are specific to $\mathrm{K}_{\mathrm{Ca}} 3.1$.

The role of $\mathrm{K}_{\mathrm{Ca}} 3.1$ in HLMC and T cell mediated secretion is to maintain the negative membrane potential during cell activation, counteracting the tendency for $\mathrm{Ca}^{2+}$ influx to depolarise the cell membrane. Thus, $\mathrm{K}_{\mathrm{Ca}} 3.1$ increases the driving force for $\mathrm{Ca}^{2+}$ influx because store operated $\mathrm{Ca}^{2+}$ channels conduct larger currents at negative membrane potentials. ${ }^{111} 13$ However, the role of this channel in cell migration is predicted to be different. A $\mathrm{K}_{\mathrm{Ca}}$ channel with some properties of $\mathrm{K}_{\mathrm{Ca}} 3.1$ has been demonstrated in glial cells and has been proposed to facilitate the retraction of the rear body of the migrating cell, ${ }^{24} 25$ despite appearing to be more highly expressed at the leading edge of lamellipodia in migrating MDCK-F (transformed renal epithelial cells), NIH-3T3 fibroblasts, and human melanoma cells. ${ }^{26}$ The mechanism controlling their seemingly selective activation at the rear body of the cell is unclear, although the localised $\mathrm{Ca}^{2+}$ concentration is likely to be critical. In addition, migration appears to require the opening and closing of the channels, most probably due to calcium oscillations, since both $\mathrm{K}_{\mathrm{Ca}} 3.1$ channel blockers and the opener 1-EBIO all inhibit chemotaxis in these cells. ${ }^{1424}$ The intermittent activation of the $\mathrm{K}_{\mathrm{Ca}}$ 3.1-like channel in these cells is therefore believed to facilitate the swelling and shrinking of the cell body required for cell migration, ${ }^{25}$ and would explain why functional $\mathrm{K}_{\mathrm{Ca}} 3.1$ are important for migration in HLMC.

CXCL10 increases intracellular $\mathrm{Ca}^{2+}$ transiently in HLMC through the release of $\mathrm{Ca}^{2+}$ from internal stores but does not activate $\mathrm{Ca}^{2+}$ influx from the extracellular fluid. ${ }^{4}$ We have shown in this study that CXCL10 does not directly open $\mathrm{K}_{\mathrm{Ca}} 3.1$, which is in keeping with our previous finding that influx of extracellular $\mathrm{Ca}^{2+}$ is the critical requirement for $\mathrm{K}_{\mathrm{Ca}} 3.1$ opening during HLMC activation. ${ }^{10}$ In addition, SCF does not open $\mathrm{K}_{\mathrm{Ca}} 3.1 .{ }^{10}$ This indicates that the gating of $\mathrm{K}_{\mathrm{Ca}} 3.1$ during HLMC migration is downstream of the chemoattractant stimulus, most probably related to adhesive signals required for the migratory process. These data also show that, while the $\mathrm{K}_{\mathrm{Ca}} 3.1$ channel in HLMC is known to be directly coupled to the $\mathrm{G}_{\alpha \mathrm{s}}$ dependent $\beta_{2}$ adrenoceptor, ${ }^{17}$ it is not coupled to the $\mathrm{G}_{\alpha \mathrm{i}}$ dependent CXCR3 receptor.

We have previously shown that HLMC proliferate in long term culture. Following an initial decrease in cell number over the first week, HLMC proliferate so that by 4 weeks there can be up to four times the starting number. ${ }^{16}$ Interestingly, in contrast to published observations in $\mathrm{T}$ and B cell ${ }^{27} 28$ and endothelial cells, ${ }^{29}$ TRAM-34 had no significant effect on HLMC proliferation. TRAM-34 inhibits mitogenesis of preactivated human $\mathrm{T}$ cells at concentrations similar to those required for channel blocking. ${ }^{27}$ In contrast to TRAM-34, clotrimazole did inhibit proliferation and, at a concentration of $1000 \mathrm{nM}$, killed HLMC, suggesting that this effect was independent of $\mathrm{K}_{\mathrm{Ca}} 3.1$ blockade (fig $1 \mathrm{~A}$ ). Clotrimazole has many diverse effects on cells other than channel blocking - for example, reducing the expression of $\mathrm{G}_{1}$ phase cyclins, ${ }^{30}$ modulation of cytochrome $\mathrm{P} 450$ activity, ${ }^{31}$ and inhibition of cellular glycolysis ${ }^{32}$-all of which could contribute to the antiproliferative effects presented here. These data suggest that SCF induced HLMC proliferation does not involve $\mathrm{K}_{\mathrm{Ca}} 3.1$, unlike acute $\mathrm{T}$ cell mitogenic stimulation with anti-CD3. ${ }^{15}$
Blockade of $\mathrm{K}_{\mathrm{Ca}} 3.1$ has shown promise in several diseases/ disease models. Clotrimazole was very effective in ameliorating active human rheumatoid arthritis but caused unacceptable side effects due to inhibition of cytochrome P450.33 TRAM-34 prevents vascular restenosis after balloon angioplasty in rats through its ability to inhibit neointimal vascular smooth muscle proliferation and without any undue toxicity. ${ }^{34}$ Another specific $\mathrm{K}_{\mathrm{Ca}} 3.1$ blocker, 4-phenyl-4H-pyran $\left(K_{\mathrm{d}} 8 \mathrm{nM}\right)$, reduces infarct volume in a rat model of subdural haematoma, suggesting a possible use in the management of traumatic brain injury. ${ }^{35}$ Clinical trials are also underway to study the effects of $\mathrm{K}_{\mathrm{Ca}} 3.1$ inhibition in sickle cell anaemia. These studies of $\mathrm{K}_{\mathrm{Ca}} 3.1$ blockade are encouraging, and the lack of obvious toxicity of TRAM-34 suggests real therapeutic potential for human disease. With regard to mast cell mediated disease, however, further mechanistic studies of $\mathrm{K}_{\mathrm{Ca}} 3$.1 blockade using rodent models are unlikely to be informative because $\mathrm{K}_{\mathrm{Ca}} 3.1$ currents have not been observed in rodent mast cells. ${ }^{8}$

In summary, we have shown for the first time that blockade of the $\mathrm{K}^{+}$channel $\mathrm{K}_{\mathrm{Ca}} 3.1$ markedly attenuates the chemotactic response of ex vivo HLMC to both the chemokine CXCL10 and the mast cell growth factor SCF, as well as TNF $\alpha$ stimulated asthmatic ASM supernatants. This suggests that blocking $\mathrm{K}_{\mathrm{Ca}} 3.1$ has great potential as a target for the treatment of asthma and other inflammatory diseases in which mast cells play a role.

\section{Authors' affiliations}

G Cruse, S M Duffy, C E Brightling, P Bradding, Institute for Lung Health, Department of Infection, Immunity and Inflammation, University of Leicester Medical School, Glenfield Hospital, Leicester, UK

This study was supported by the Wellcome Trust.

Competing interests: none.

\section{REFERENCES}

1 Bradding P, Holgate ST. Immunopathology and human mast cell cytokines. Crit Rev Oncol Haematol 1999;31:119-33.

2 Brightling CE, Bradding P, Symon FA, et al. Mast cell infiltration of airway smooth muscle in asthma. N Engl J Med 2002;346:1699-706.

3 Tetlow LC, Woolley DE. Distribution, activation and tryptase/chymase phenotype of mast cells in the rheumatoid lesion. Ann Rheum Dis 1995;54:549-55.

4 Brightling CE, Kaur D, Berger P, et al. Differential expression of CCR3 and CXCR3 by human lung and bone marrow-derived mast cells: implications for tissue mast cell migration. J Leukoc Biol 2005;77:759-66.

5 Brightling CE, Ammit AJ, Kaur D, et al. The CXCL10/CXCR3 axis mediates human lung mast cell migration to asthmatic airway smooth muscle. Am J Respir Crit Care Med 2005;171:1103-8.

6 Kassel O, Schmidlin F, Duvernelle C, et al. Human bronchial smooth muscle cells in culture produce stem cell factor. Eur Respir J 1999;13:951-4.

7 Berger P, Girodet PO, Begueret H, et al. Tryptase-stimulated human airway smooth muscle cells induce cytokine synthesis and mast cell chemotaxis. FASEB J 2003;17:2139-41.

8 Bradding P. Mast cell ion channels. Chem Immunol Allergy 2005;87:163-78.

9 Chandy KG, Wulff $\mathrm{H}$, Beeton $\mathrm{C}$, et al. $\mathrm{K}^{+}$channels as targets for specific immunomodulation. Trends Pharmacol Sci 2004;25:280-9.

10 Duffy SM, Lawley WJ, Conley EC, et al. Resting and activation-dependent ion channels in human mast cells. J Immunol 2001;167:4261-70.

11 Duffy SM, Berger $\mathrm{P}$, Cruse $\mathrm{G}$, et al. The $\mathrm{K}^{+}$channel $\mathrm{iK}_{\mathrm{CA}} 1$ potentiates $\mathrm{Ca}^{2+}$ influx and degranulation in human lung mast cells. J Allergy Clin Immunol 2004; 114:66-72.

12 Kaur D, Berger P, Duffy SM, et al. Co-cultivation of mast cells and Fc epsilon RI alpha+ dendritic-like cells from human hip bone marrow. Clin Exp Allergy 2005:35:226-33.

13 Hoth $M$, Penner R. Depletion of intracellular calcium stores activates a calcium current in mast cells. Nature 1992;355:353-6.

14 Schilling T, Stock C, Schwab A, et al. Functional importance of $\mathrm{Ca}^{2+}$-activated $\mathrm{K}^{+}$channels for lysophosphatidic acid-induced microglial migration. Eur J Neurosci 2004;19:1469-74.

15 Jensen BS, Odum N, Jorgensen NK, et al. Inhibition of T cell proliferation by selective block of $\mathrm{Ca}(2+)$-activated $\mathrm{K}(+)$ channels. Proc Natl Acad Sci USA 1999;96:10917-21.

16 Duffy SM, Lawley WJ, Kaur D, et al. Inhibition of human mast cell proliferation and survival by tamoxifen in association with ion channel modulation. J Allergy Clin Immunol 2003; 112:965-72.

17 Duffy SM, Cruse G, Lawley WJ, et al. Beta(2)-adrenoceptor regulation of the $\mathrm{K}^{+}$channel $\mathrm{iK}(\mathrm{Ca}) 1$ in human mast cells. FASEB J 2005; 19:1006-8. 
18 Jones SE, Kelly DJ, Cox AJ, et al. Mast cell infiltration and chemokine expression in progressive renal disease. Kidney Int 2003;64:906-13.

19 Gimenez-Gallego G, Navia MA, Reuben JP, et al. Purification, sequence, and model structure of charybdotoxin, a potent selective inhibitor of calciumactivated potassium channels. Proc Natl Acad Sci USA 1998:85:3329-33.

20 Wulff H, Gutman GA, Cahalan MD, et al. Delineation of the clotrimazole/ TRAM-34 binding site on the intermediate conductance calcium-activated potassium channel, IKCal. J Cell Chem 2001;276:32040-5.

21 Logsdon NJ, Kang J, Togo JA, et al. A novel gene, hKCa4, encodes the calcium-activated potassium channel in human T lymphocytes. J Biol Chem 1997;272:32723-6.

22 Bradding P, Okayama Y, Kambe N, et al. lon channel gene expression in human lung, skin, and cord blood-derived mast cells. J Leukoc Biol 2003:73:614-20.

23 Wulff $H$, Miller MJ, Hansel W, et al. Design of a potent and selective inhibitor of the intermediate-conductance $\mathrm{Ca}^{2+}$-activated $\mathrm{K}^{+}$channel, IKCal: a potential immunosuppressant. Proc Natl Acad Sci USA 2000;97:8151-6.

24 Schwab A, Schuricht B, Seeger $P$, et al. Migration of transformed renal epithelial cells is regulated by $\mathrm{K}^{+}$channel modulation of actin cytoskeleton and cell volume. Pflugers Arch 1999;438:330-7.

25 Schneider SW, Pagel P, Rotsch C, et al. Volume dynamics in migrating epithelial cells measured with atomic force microscopy. Pflugers Arch 2000:439:297-303.

26 Schwab A, Wulf A, Schulz C, et al. Subcellular distribution of calciumsensitive potassium channels (IK1) in migrating cells. J. Cell Physiol 2006;206:86-94
27 Ghanshani S, Wulff H, Miller MJ, et al. Up-regulation of the IKCal potassium channel during T-cell activation. Molecular mechanism and functional consequences. J Biol Chem 2000;275:37137-49.

28 Wulff $\mathrm{H}$, Knaus $\mathrm{HG}$, Pennington $\mathrm{M}$, et al. $\mathrm{K}^{+}$channel expression during $\mathrm{B}$ cell differentiation: implications for immunomodulation and autoimmunity. $J$ Immunol 2004; 173:776-86.

29 Grgic I, Eichler I, Heinau P, et al. Selective blockade of the intermediateconductance $\mathrm{Ca}^{2+}$-activated $\mathrm{K}^{+}$channel suppresses proliferation of microvascular and macrovascular endothelial cells and angiogenesis in vivo. Arterioscler Thromb Vasc Biol 2005;25:704-9.

30 Aktas H, Fluckiger R, Acosta JA, et al. Depletion of intracellular $\mathrm{Ca} 2+$ stores, phosphorylation of elF2 alpha, and sustained inhibition of translation initiation mediate the anticancer effects of clotrimazole. Proc Natl Acad Sci USA 1998;95:8280-5.

31 Zhang W, Ramamoorthy Y, Kilicarslan T, et al. Inhibition of cytochromes P450 by antifungal imidazole derivatives. Drug Metab Dispos 2002;30:314-8.

32 Penso J, Beitner R. Clotrimazole decreases glycolysis and the viability of lung carcinoma and colon adenocarcinoma cells. Eur J Pharmacol 2002:45:227-35.

33 Woitulewski JA, Gow PJ, Walter J, et al. Clotrimazole in rheumatoid arthritis. Ann Rheum Dis 1980;39:469-72.

34 Kohler R, Wulff H, Eichler I, et al. Blockade of the intermediate-conductance calcium-activated potassium channel as a new therapeutic strategy for restenosis. Circulation 2003;108:1119-25.

35 Urbahns K, Horvath E, Stasch JP, et al. 4-Phenyl-4H-pyrans as IK(Ca) channel blockers. Bioorg Med Chem Lett 2005; 13:2637-9.

\section{LUNG ALERT}

\section{Lung cancer is more common but less often fatal in women}

A International Early Lung Cancer Action Program Investigators. Women's susceptibility to tobacco carcinogens and survival after diagnosis of lung cancer. JAMA 2006;296:180-4

ung cancer is on the rise, especially in women. Previous studies have suggested that women have a higher relative risk of developing lung cancer. This large follow up study from the International Early Lung Cancer Action Programme (ELCAP) investigators was designed to assess the risk of lung cancer related to smoking in women compared with men. Survival after diagnosis was also evaluated, using the data from the present study combined with those from the original ELCAP study.

An additional 6296 women and 8139 men (all asymptomatic) were screened with baseline CT scans. All patients with lung nodules underwent immediate biopsy or surgical resection. A panel of five expert lung pathologists reported the histological samples.

Lung cancer was diagnosed in $111 / 6296$ women $(1.7 \%)$ and 93/8139 men $(1.1 \%)$. Combining the two series together, lung cancer was diagnosed in 156/7498 women $(2.1 \%)$ and $113 / 9427$ men (1.2\%). This gave an odds ratio of cancer in women of 1.9 (95\% CI 1.5 to $2.5)$ corrected for age and pack-year smoking history. It was also noted that survival was better in women, regardless of the stage of lung cancer and after matching for cell type and treatment. The hazard ratio for a fatal outcome in women was 0.48 (95\% CI 0.25 to 0.89 ). This is an interesting result, but the authors could not find any specific reason for the difference in survival. It has been suggested that lung cancer in women may be less aggressive or relatively more curable than in men, and this needs to be evaluated further.

M S Anwar

Respiratory Registrar, Whipps Cross University Hospital, London, UK; Muhammad.anwar@whippsx.nhs.uk 